\title{
Assessing the Potential Role of Inland Water Navigation for Green Economy
}

\author{
${ }^{1, \#}$ Nidhi Nagabhatla and ${ }^{2}$ Prakhar Jain \\ ${ }^{1, \#}$ Institut für Umweltplanung (IUP), \\ Gottfried Wilhelm Leibniz Universität, Hannover,30419,Germany \\ ${ }^{2}$ School of Geography and the Environment, \\ University of Oxford, Oxford, United Kingdom \\ ${ }^{\#}$ Corresponding Author:
}

Tel.: (49) 511762 19540; Fax: (49) 511762 19538; E-mail- nidhi26@gmail.com

\begin{abstract}
On one hand, the authors explore transport and trade as two broad service sectors of inland water resources. On the other hand, attempt is made to link the services from this sector with the evolving understanding of Green Economy. The first section explains the historical background of Inland Water Transport (IWT) sector along with the discussion of options that can channel its optimum efficiency. The authors state that co-operation and co-ordination between trans-boundary governments is a strategic element to expand the network of inland water transport beyond national boundaries. The second section presents a comparison of river transportation system with surface road-rail network to explain prospective contribution of IWT for green economic growth. Conclusively, the prospect of inland navigation looks promising, wherein issues on infrastructural gaps and institutional support are addressed suitably.
\end{abstract}

KEYWORDS: Inland water navigation, Transportation, National waterways, Green Economy

\section{Introduction}

Inland waterways are historically recognized as vital arteries for communication and transport especially for the rural people (Rangaraj and Raghuram, 2007). With spread of globalization, the traditional culture of small distance transport using inland waters was substituted by land, air, marine systems. This transformation left the inland waterways as a de-prioritized and neglected sector. Until today, rivers in urban centers and rural areas of developing countries constitute of small, nonmechanized country boats often used for transport, trading and livelihoods .One often refers to the populations along waterways as half-amphibious for the reason that a water body is centric to their way of life and to the economy of their household. Inland water transport (hereafter referred as IWT) remained localized over many decades and did not scale to its potential capacity to emerge as a 
structured, formalized and institutionalized system in India. The above statement is based on two studies. First, that IWT contributes 32 percent of the total transport sector in Bangladesh (Nishat, 2001 and Rahaman, 2009) and second, it constitutes a fractional stake (0.15 percent) in India (Raghuram, 2004).

Common understanding complimented with scientific analysis support the fact that water-based transport is largely fuel efficient and more environmentally responsive when compared to road, rail, or air (Eastman, 1980). India has an estimated 14500 $\mathrm{km}$ of navigable inland waterways, including river systems, canals, backwaters, creeks and tidal inlets that can effectively support mechanized crafts. Records state about $5200 \mathrm{~km}$ of major rivers and $485 \mathrm{~km}$ of canals channels as suitable for inland transport (Directorate General of Shipping,2009-2010), India. It further reports that total cargo moved by inland water transport is about 20 million tons, compared to over 1.5 billion tones [0.15per cent of the total inland cargo of nearly 877 billion tones] managed by road, rail and pipelines.

In order to regulate inland waterways, Government of India instituted (also for compliance of Inland Waterways Authority of India Act (1985) Inland Water Authority of India (IWAI) (IWAI-2008,http://iwai.nic.in/). The organization got functional in 1986 with a mandate to facilitate the commercial and non-commercial use of channel systems. Operational zones refereed as National Waterways [NW] restrict to national jurisdiction with defined emphasis on shipping and navigation. Table1 and Figure1 show Indian NW routes. The key interventions include: control of shifting bed, guarding of scouring current action, and dredging and information dissemination on navigable depth of channels to fisherman and traders.

It has become increasingly significant that sectoral interventions and development plans link with sustainability goals. On one hand, water is focus for regional development (Ahmad et al, 2004) and environmental sustainability (Ahmad et al., (2001; Biswas et al, 2001, 2004). On other hand, Green Economy targets are emerging compelling nations to factor green growth options in their development planning.

Green Economy vision is not a replacement for sustainable development, although fair degree of overlap is noted, such as: propagation of low carbon frameworks, adoption of approaches that target resource efficiency and aiming socially inclusive growth (UNEP-2011).The authors take the challenge to explore the synchrony in IWT and Green Economy. For the sake of clarity on Green Economy, the authors refer to the concept by United Nations Environmental Program. This framework emphasizes on retaining or improving human well-being, reducing environmental and ecological risk while balancing the economic growth as key goals of green economic growth. The script focuses on the Ganges basin and illustrates the prospect of Inland Water Navigation, which if supported by appropriate national policies can successfully compete in efficiency and cost with surface freight transportation sector. Consideration is given to the fact that Inland Water 
Navigation sector can be significant relevance for addressing climate change mitigation process.

Table 1: Major (existing and proposed) national waterways of India and their geographical stretch

\begin{tabular}{|c|c|c|}
\hline Series Number & Name and Stretch & $\begin{array}{l}\text { Geographic } \\
\text { Extent }\end{array}$ \\
\hline $\begin{array}{l}\text { *National Waterway } \\
\text { No.1(NWI) }\end{array}$ & $\begin{array}{l}\text { Ganga between Allahabad-Haldia (1620 } \\
\text { km) }\end{array}$ & $\begin{array}{l}\text { UP,Bihar, } \\
\text { Jharkhand and } \\
\text { West Bengal }\end{array}$ \\
\hline $\begin{array}{l}\text { National Waterway } \\
\text { No.2 (NWII) }\end{array}$ & $\begin{array}{l}\text { Sadiya-Dhubri stretch of river Brahmaputra } \\
(891 \mathrm{~km})\end{array}$ & Assam \\
\hline $\begin{array}{l}\text { National Waterway } \\
\text { No.3(NW: III) }\end{array}$ & $\begin{array}{l}\text { Kollam-Kottapuram stretch of West Coast } \\
\text { Canal along with Champakara and } \\
\text { Udyogmandal Canals }(205 \mathrm{~km})\end{array}$ & Kerala. \\
\hline $\begin{array}{l}\text { Two proposed Water } \\
\text { National Waterway } \\
\text { No.4(NWIV) }\end{array}$ & $\begin{array}{l}\text { ays ( recently declared) } \\
\text { Kakinada-Puducherry stretch of Canals and } \\
\text { the Kaluvelly Tank, Bhadrachalam - } \\
\text { Rajahmundry stretch of River Godavari and } \\
\text { Wazirabad - Vijayawada stretch of River } \\
\text { Krishna ( } 1095 \mathrm{~km})\end{array}$ & Andhra Pradesh \\
\hline $\begin{array}{l}\text { National Waterway } \\
\text { No. } 5(\mathrm{NWV})\end{array}$ & $\begin{array}{l}\text { The Talcher-Dhamra stretch of river } \\
\text { Brahmani, Geonkhali-Charbatia stretch of } \\
\text { East Coast Canal, Charbatia-Dhamra stretch } \\
\text { of Matai river and Mangalgadi-Paradip } \\
\text { stretch of Mahanadi delta rivers }(623 \mathrm{~km}) \text {. }\end{array}$ & Dhamra, Orrissa \\
\hline
\end{tabular}

Source: Inland Waterways Authority of India (IWAI) database

The waterway selected for analysis is National waterway number 1 (source IWAI)

At the same time the authors highlight the limiting factors such as outdated infrastructural facilities, inefficient maintenance and unorganized terminal facilities around river landscape as few among many factors that undermines the productive use of inland water resources, in spite of its carbon positive tendency. In context of above background, the article presents a line of discussion on possible interventions that can facilitate optimizing the resource efficiency of this sector.

\section{National Inland Waterway 1}

For centuries, Ganges and its principal tributaries servers route of trade and commerce (Biswas, 1992). Ancient Greek historian (Megasthenes) quotes that, Ganges and its main tributaries were navigated from 4BCand inland navigation flourished then. Whilst Irrigation-cum-navigation canals for water-transport system (also connecting the inland regions to ports) have begun to exist as early as $19^{\text {th }}$ Century reports Plether, (2011). 


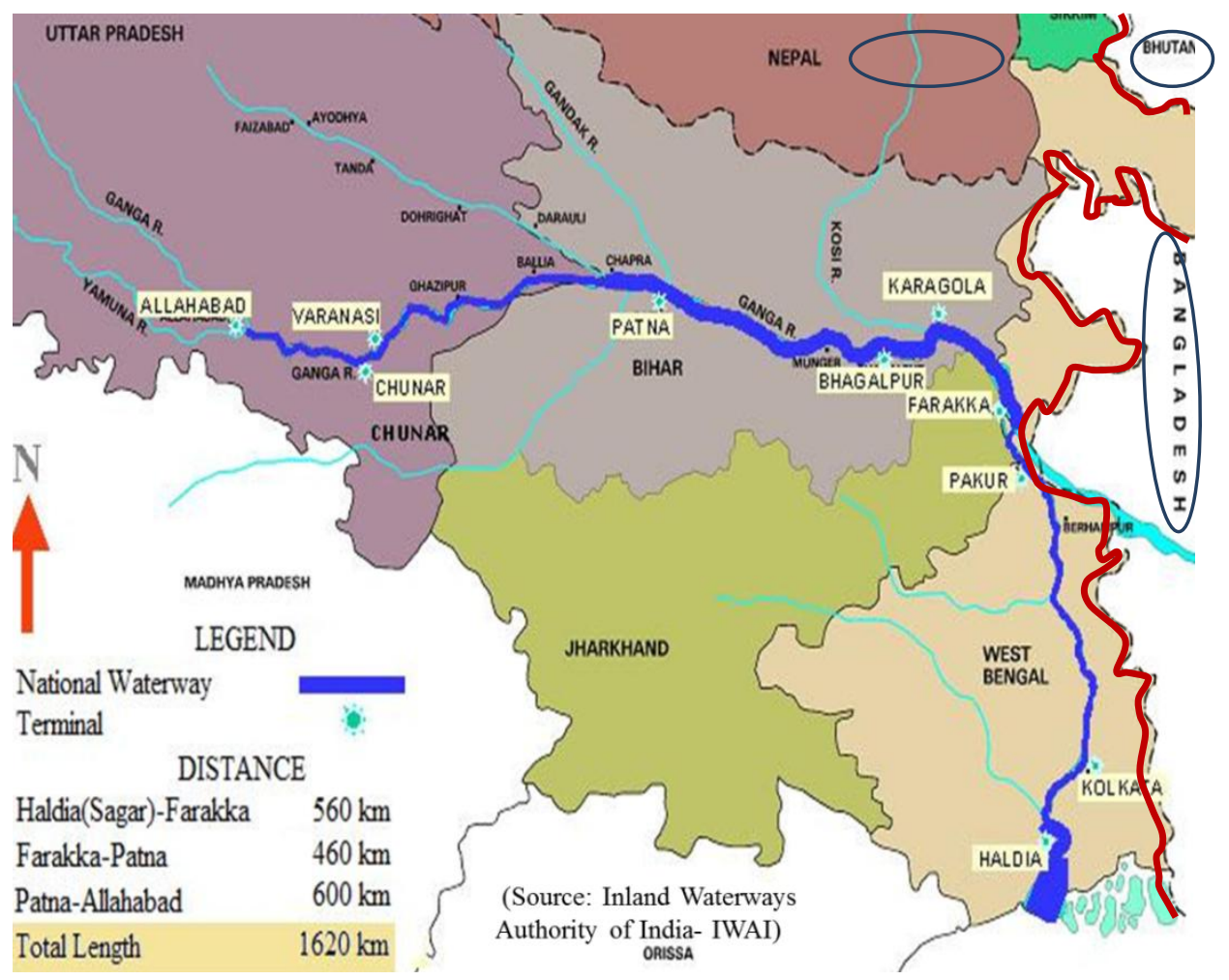

Figure 1: National Waterway No1 (NW1) in the Indo-Gangetic basin stretching between Allahabad-Haldia is projected to be waterways that can facilitate trans-boundary trade relations with Nepal and Bangladesh

The advent of paddle steamers revolutionized inland transport, stimulating the growth of indigo production in Bihar and Bengal (Arnold, 2000). Regular steamer services plied through Ganges from Kolkata to Allahabad and beyond. Currently, this route is refereed as National Waterway I (NW-1). Statistics from IWAI support the navigability of Ganges channel stating the Least Available Depth (LAD-is the minimum depth required for sailing) as $2 \mathrm{~m}$ (between Haldia and Patna) and this depth is available for more than $60 \%$ of the annual length. The vessels on NW-1 are operated by federal owned enterprise CIWTC [Central Inland Water Transport Corporation] while some private actors have as take too.

Importance of inland navigation has not gained the expected momentum in recent years especially after the shift of transport to roads and rails. In North-Eastern India, traffic (including a large propositions of livelihood activities) is still dependent on waterways, so river navigation could gain priority for better development when compared to other regions in the country (Verghese et al., 2006). The value of inland channels becomes all the more critical during events of heavy rainfall and monsoonal aberrations that would often result in the heavy inundation hence 
disturbing the modes of connectivity by land (CCC, 2009).Throughout the year, main channels of Ganges [NW-1] and its larger tributaries are navigable (Gopal, 2004) with main terminals at Haldia, Kolkata, Pakur, Farakka, Karagola, Bhagalpur, Munger, Patna and Allahabad.The cargo traffic (in tonnes) for NW-1 is illustrated in Figure 2.

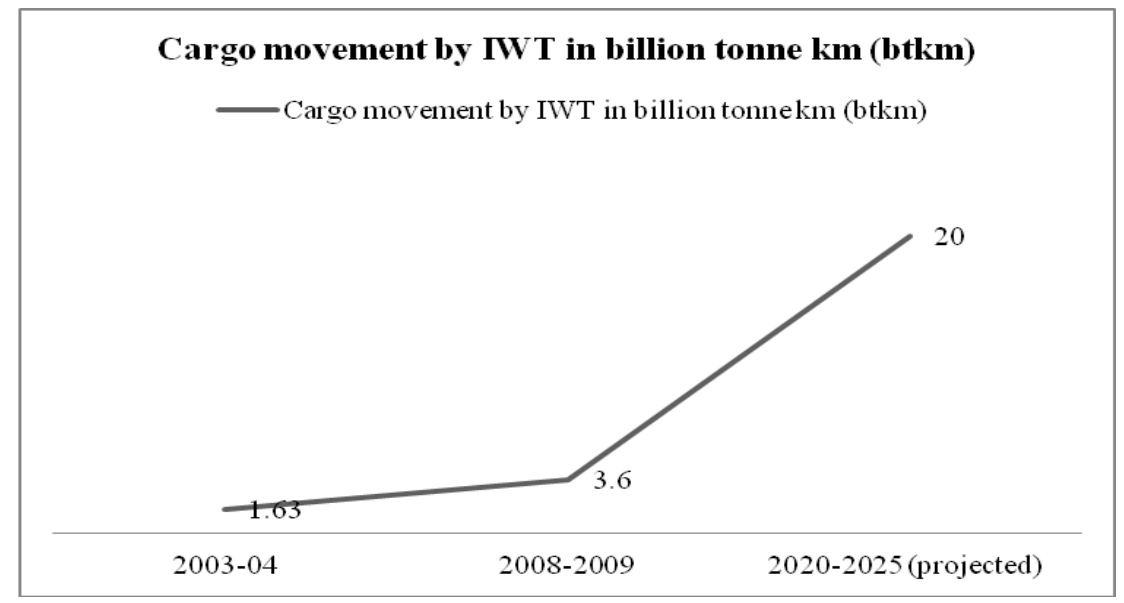

Figure 2a: Projected trend of total cargo movement by Inland Water Transport (IWT)

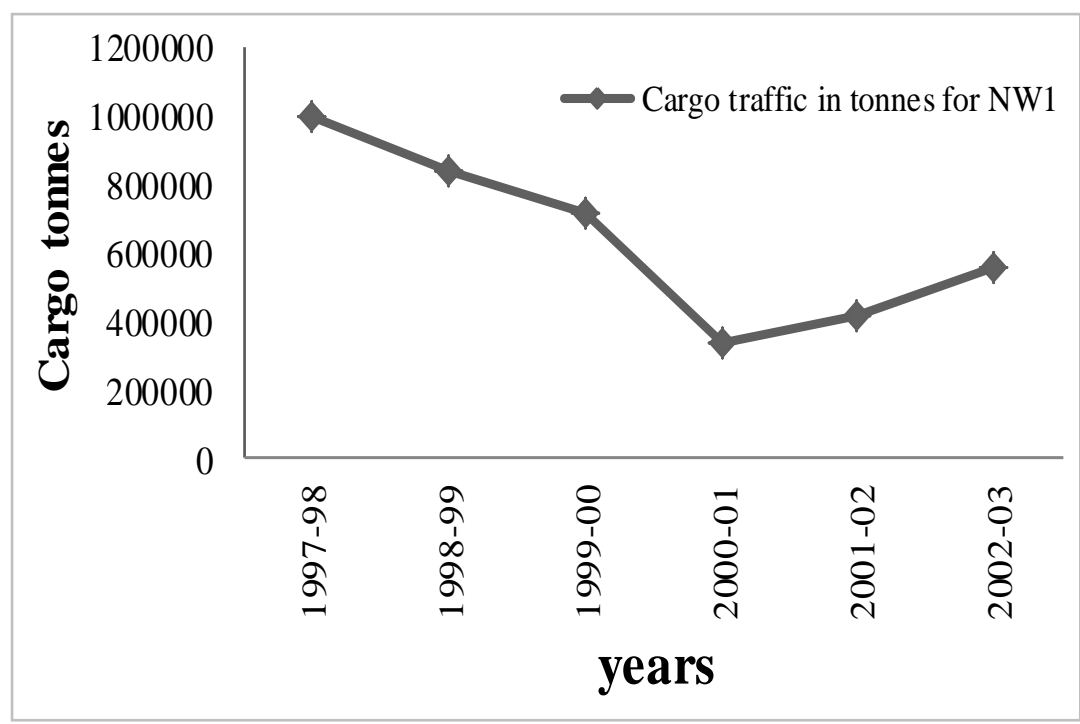

Source: Annual Report of Inland Water Authority of India

Figure 2b: Trend in the Cargo Traffic for National Waterway-1 has not looked very positive in recent years with sharp decline noted in 2000 


\section{Discussion}

The article is a contribution to the enhanced understanding of inland transport. This section is the key component of the manuscript and is explained in two segments: (1) the promising potential of IWT, and (2) how it connects with the green economy objectives.

\section{First Segment: Inland Navigation: Challenges and Opportunities}

National Waterways are of significance for their role in inland cargo transportation and as local communication routes (NCAER-2006). Howsoever, existing navigable waterways lack needed infrastructure, navigational aids, terminals and communication facilities and institutional / policy support (Nair, 2005). Inland navigation during wet season is regarded crucial, as during this time land based communication systems (roads) often suffer critical damage from the impact of extreme rainfall, rendering them not suitable for use (Koetse and Rietveld, 2009). At such a time navigation through water is supports transport connectivity for man and cargo (GAO, 2011).

- National Water Management Agenda: Priorities and Policies: In water resources development agenda of India, navigation is relegated at the end after issues of drinking water, irrigation and power (hydel) sector (Planning Commission, 2006). This reflects the level on importance given to the sector in terms of budget allocation, employment in the sector and policy. The sector deems improved priority to be optimized to its potential.

- Trans boundary issues :structural and political: Most inland waterways, like river systems are trans boundary in nature that means the originating country of river can be different to the country where it finally meets the sea. For example, the NW-1 (Ganges channel between Allahabad-Haldia that stretches $1620 \mathrm{~km}$ ) downstream closely link with the inland border channel between India and Bangladesh and similar reasoning can made for NW-2 the Sadiya-Dhubri stretch of river Brahmaputra $(891 \mathrm{~km})$. Reports suggest, historically the cross-boundary channels were navigated under regional connections and collaborations, the practice that come to almost a close in recent time A national level, the big challenge is the lack of coordination between the state governments and local authorities managing IWT, at cross-country level, stakeholders of river systems such as Ganges, Brahmaputra, Meghna lack cooperation and political agreement essential for the functioning of inland waterways. Dealing with prevailing political bureaucracy, especially hydro-diplomacy in the region [India and Bangladesh], it is interesting to take reference of the historical treaties shared between these countries (Bandyopadhyay and Ghosh, 2009).

- Knowledge base and Information sharing on hydrology of inland navigation: Least Available Depth (LAD) is a critical parameter driving the 
navigation hydraulics of inland channels. Strengthening capacity of communities, businesses with scientifically calibrated up-to-date information on changing depth of inland water and hydrological changes (as of seasonality effect or other water regulation, allocation/distribution systems)is an obligatory requirement. Addressing excessive siltation in major rivers from erosion of uplands and deforestation are supplementary issues that need attention for improving IWT operations.

- Infrastructural Interventions: Unavailability of low draft high technology vessels is another limiting factor. Installment and construction of better navigational aids could possibly increase long time sailing (also during darkness). Figure 3 reflects current cost of Rs. 3.55 -Rs.1.44 for a short haul of $100 \mathrm{~km}$ and from Rs. $0.95-0.39$ for a long haul of $2000 \mathrm{~km}$. Building permanent terminals for adequate and efficient loading and unloading of cargo facilitates trade options. IWAI states mechanized handling at terminals and night navigation facilities as requisite (implementation yet due).

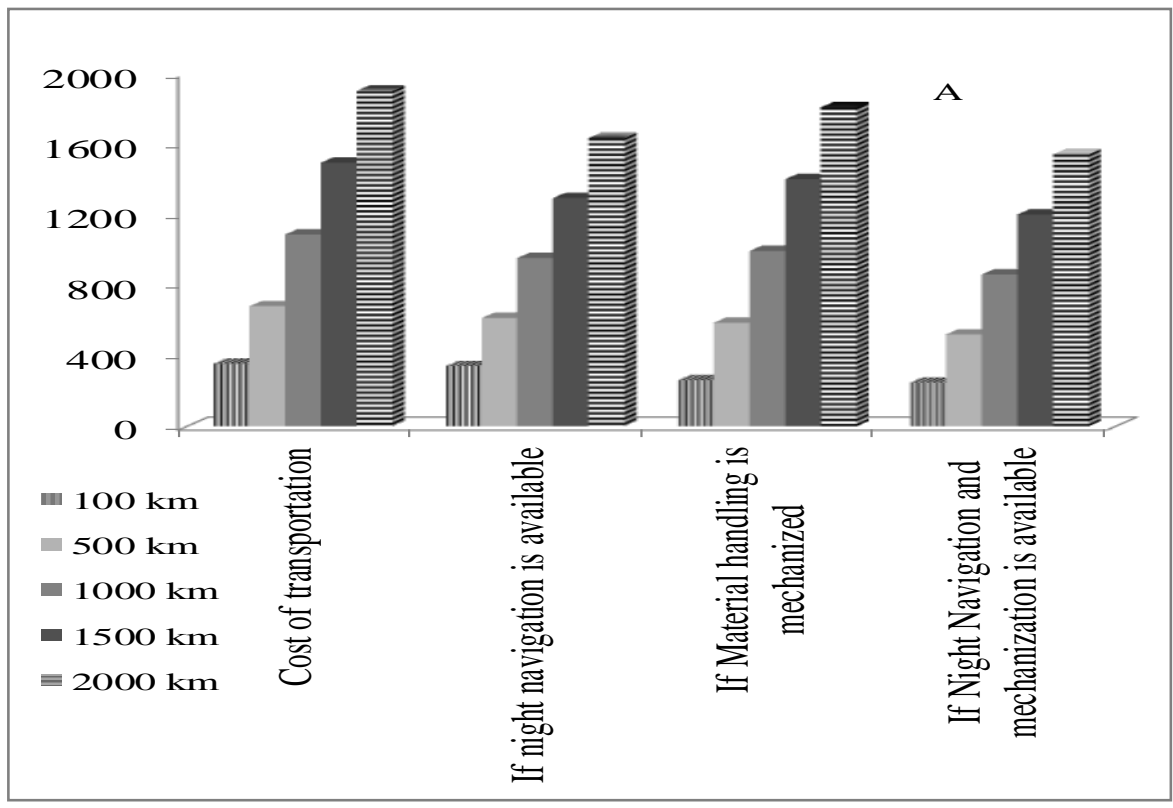

Figure 3a: Cost of (in Indian National Rupees/Tonne) Transportation by IWT for one way cargo

- Involvement of private sector: Private sector involvement is projected to play a key role for IWT. Improved terminal and warehousing facilities, mechanization of the cargo-handling system, installation of the new navigational aids and maintenance of the existing infrastructure are dimensions requiring attention. In addition maintaining fairway, providing 
pilot age services, setting up of IWT training facilities are undertakings of equal requirement. Considering, several levels of possible private sector integration with IWT development plans (coordinated by state agencies such as IWAI), Joint ventures viz. Build-Operate-Transfer (BOT) scheme, can be negotiated under Public-Private-Participation framework. Alternate way of engagement is to leverage from set of defined incentives as expounded in the dossier of the Directorate General of Shipping (2009). Private sector players (Hindustan Lever, Ambuja Cements and many others) are currently engaged with IWT. Besides public limited enterprises that include IOCL [Indian Oil Cooperation], Haldia Petrochemicals, FCI [Food Cooperation of India], ONGC [Oil and Natural Gas Commission] and Hindustan Paper Corporation are also in joint operations. With supportive policies, private sector involvement can be expanded.

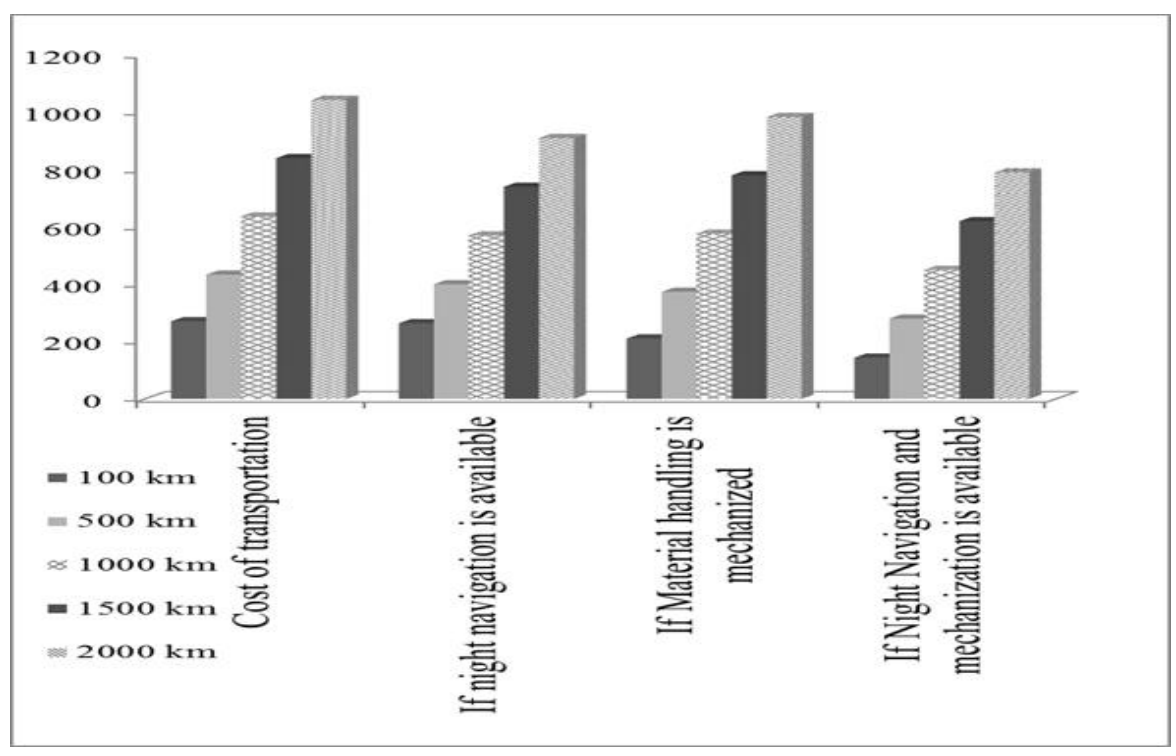

Figure 3b: Cost of transportation by IWT for two way cargo

[Source: Directorate General of Shipping, Government of India]

- Navigational and Operational facilities: IWAI coordinates existing IWT facilities. Presence of lock gate at Farakka and barrage system at Kolkata port ensures navigability for NW-1. However, hydro-dynamics seasonality is a dimension demanding better attention. For example, during winters, the available depth for Ganges is 4-4.5meter, during summer and 10- $12 \mathrm{~m}$ during monsoon. Factoring this variation while designing and operating navigational facilities is important. Like such, floating terminals are preferred for IWT for narrow channel width and for banks inward and outward pushing. Hydrological complexity of inland channels demands tailored requirements for IWT. Taking the reference of an incident where the conventional battery operated type buoys provided on NW-1 waterway, 
are often pilfered, rendering these facilities un-available when required, especially during night navigation. To resolve similar situation, beacon type markers (also used in NW III) are less susceptible to thefts. Exchange of experiences between local-level authorities can be effective for maintenance and management of NW's.

\section{Second Segment: Inland Water Navigation vis-à-vis Green Economy}

To project a strengthened regional trade in South Asia and improve bilateral links, IWT established in coordination with the doctrines of greening the economic growth sounds as a promising option. Take the case of remote industrially (mining) active areas of North-east India (including Bihar, Bengal) that are landlocked and transport mined products mostly by road. NW-1 provides an alternative route for goods to be directly transported to Kolkata (or Mongla) port India (Bangladesh) facilitating national and cross-country trade. Similar possibilities stand for Nepal. Three major tributaries of Ganges: Karnali, Gandaki and Kosi exhibits high probability of connection with NW-1.Main water channel of Nepal, river Kosi River, though non-navigable upstream as of steep terrain can be connected by lowdraft barges downstream. To sum, infrastructural arrangements complimented by trans-boundary institutional arrangements is a pre-requisite. Border shared by India and Nepal has Karnali River (or Ghagra in India) flowing to the confluence of Ganges that shows good prospect for navigation (Biswas et al., 2007). Kayastha (2001) proposed o extendNW-1 (from Allahabad to Hadia) to link with Gandaki River while joining central Nepal, eastern Uttar Pradesh and eastern Bihar.

India and Bangladesh have a bilateral protocol, renewed every two years, for India to use the Ganges-Brahmaputra-Meghan river way for water transit between West Bengal and Assam (Verghese, 2001). Taking reference of existing arrangement between two countries further facilitation can go long way to address above concerns, not just for national level economic growth, also for regional development. Green Economy is a newly sorted target both for developed and developing economies. The article attempts to explain prospective practices and process.

- Low capital and maintenance cost: Estimations show that developing and building an inland waterway costs about 5-10 per cent to that of 4-lane highway/railway (IWAI-200809), making it a lucrative transportation option with low capital investment. In India, maintenance cost of IWT is assessed at $20 \%$ that of road. Department of Shipping (India) states that shifting cargo transport to the IWT mode will reduce transport fuel cost by 5 million USD and overall transport cost by 9 million USD (Sriraman, 2010).Other factors: local conditions of river, fuel cost, and maintenance costs will be contributing to operational cost as well. IWT may be cost intensive at the start; it is a cost-effective in long term. 
- Potential for Integrated design: Integrated transport and trade frameworks/models (ITF's) is discussed for optimisation in efficiency and economics (UNCTAD, 2008). Practically a difficult target, it demands elaborate discussions on multiple aspects (structural and functional). Let us attempt to understand; (a) Physical integration: refers to connecting different navigable (hydrological) channels (basin, upstream and downstream). For NW-I, a prospective connect between inland water routes regions (as far as Himalayas or as close as Vindhyas) to integrate with marine routes. Infrastructural structures such as dams/ barrages restrain regular water flow (and LAD) needed for IWT. Construction of bridges also restricts vertical clearances of navigation vessels (especially heavy-duty cargo).Despite endowed with numerous navigable rivers only four national waterways are functional in India (that too with low freight traffic). ITF's can address much of this concern (b) Functional Integration: refers to connection between National Highways, National Railways and National Waterways connecting these modes of transport and trade through a joint regulating authority. For example, the railway freight corridors linked with the waterways by making special tracks up to NW terminals. Haldia Dock Complex (NW-1)-inland water terminal provides possible integration point for coastal shipping with national waterways and re-distributing the cargo in waterways. Extendable to point-based-point connection with road and rail networks, it is expected to have relevant applicability and fuel-cost efficiency; (c)Structural Integration refers to achieving efficiency in integrated design by improving infrastructural/technical facilities viz., linked roads, channels, permanent berths, handling gears like shore cranes and gantries (for containers), mobile cranes, forklift trucks and trailers, storage sheds and warehouses.

- Carbon Efficiency: The goal of Green Economy framework is to minimise carbon footprint of development processes. Fuel efficiency is vital to regulate carbon emission.IWT is exceedingly fuel-efficient transport mode with an estimate that one litre fuel can transport 24 tonne $/ \mathrm{km}$ freight by $\mathrm{road}, 85$ tonne/km by rail and 105 tonne/km by waterways (IWAI-2008/09). With appropriate regulatory measures, IWT as a transport option bears competitive advantage.

\section{Conclusions}

Government of India aims to develop and harness the potential of Inland Water Navigation in order to bolster optimal and sustainable use of water systems. Setting up Inland Water Authority and declaration of National Waterways was a first step towards this objective. Even though in a broad sense, growth of IWT sector is not very aligned with development objectives, further development in this sector sounds promising as a carbon efficient alternative. Installment of $g$ better navigational aids 
and infrastructure facilities remain a key requirement to increase effectiveness of the sector.

Recently held, Rio+20 (June 20-22, 2012) kept the international governmental and civil society engaged in a debate towards common understanding of Green Economy. The challenge is see this conceptual dialogue translated to ground action. The agenda of river and water resources at Rio+20 and in a wider debate of "Green Economy" deems focus on processes and interventions that can withstand sustainable growth. In current times, efficient energy consumption and green economic future is a pressing goal, IWT sector assures to be less fuel consuming (making it a best bet to expand and develop). Building essential infrastructure like mechanized handling at terminals and night navigation facilities is pertinent. Other enabling conditions include clear framework of national level procedures, incentives, policies, and subsidies. Such stimulus can translate into cost reduction per tone-km (TKM) over short and long haul.

The authors explains energy efficiency (target of green economy) of IWT based on quantitative analysis reassuring that, if coordinated efficiently IWT can add towards accomplishment of energy objectives.Infrastructure, capacity and institutional support in place can proficiently instruct this sector beyond its current state.IWT sector promises to sustain, enhance and engage the interaction with people whose livelihoods and socio-economic security depends on inland water resource. One can note that data limitation and lack of up-to-date scientific assessments are limiting factors for timely decision making for IWT.

\section{References}

Ahmad, Q. K., A. K., Biswas, R. Rangachari and M. M. Sainju (2001) "GangesBrahmaputra-Meghna Region: A Framework for Sustainable Development", The University Press, Dhaka, 164.

Ahmad, Z. U. (2004) "Water Development Potential within a Basin-wide Approach: Ganges- Brahmaputra-Meghna Issues", In: Biswas, A. K., Unver, O., Tortajada, C. (Eds) Water as a Focus for Regional Development. Oxford University Press, 83-113.

Arnold, D. (2000). "Science, Technology and Medicine in Colonial India", Cambridge University Press. 50-55.

Bandyopadhyay, J. and N. Ghosh (2009). "Holistic Engineering and Hydro-diplomacy in the Ganges-Brahmaputra-Meghna Basin”. Economic and Political Weekly, 44(45): 50-60.

Biswas, A. K and J. I Uitto (2001) "Sustainable Development of the Ganges-BrahmaputraMeghna Basin”. United Nations University Press, Tokyo.

Biswas, A. K. (1992) "Indus Water Treaty: the Negotiating Process". Water International, 17: 201-209. 
Biswas, A. K., O. Unver and C. Tortajada (Eds) (2004) "Water as a Focus for Regional Development". Oxford University Press, Delhi.

CCC (2009) "Impact Assessment of Climate Change and Sea Level Rise on Monsoon Flooding". Climate Change Cell, DoE, MoEF; Component 4b, CDMP, MoFDM. Month 2009, Dhaka, Bangladesh.

Directorate General of Shipping (2009) “Annual Report [2009-10]”, Government of India. India, 33-45.

Eastman, S. E. (1980) "Fuel Efficiency in Freight Transportation” The American Waterway Operators, Inc. Arlington, VA, June, 7.

GAO [United States Government Accountability Office] (2011) "Surface Freight Transportation: A Comparison of the Costs of Road, Rail, and Waterways Freight Shipments That Are Not Passed on to Consumers "Report to the Subcommittee on Select Revenue Measures, Committee on Ways and Means, House of Representatives. Washington D.C. January 2011. Retrieved from: www.gao.gov.67p

Gopal, B. (2004) "State of Degradation and Approaches to Restoration of Floodplain Rivers in India" Proceedings of the second international symposium on the management of large rivers for fisheries (Volume II) (Available at ftp://ftp.fao.org/docrep/fao/007/ad526e)

IWAI-Inland Waterways Authority of India (2008) “Annual Report [2008-2009]”-Published by Department of Shipping-Ministry of Shipping, Road Transport and Highways. NoidaIndia, pp. 50.

Kayastha, R. L. (2001) "Water Resources Development of Nepal: A Regional Perspective". In: Biswas, A.K. and Uitto, J.I. (Eds) Sustainable Development of the Ganges-BrahmaputraMeghna Basin. United Nations University Press, Tokyo, 122-144

Koetse, M. J. and P. Rietveld, (2009) "The impact of climate change and weather on transport: An overview of empirical findings" Transportation Research Part D. 14: 205-221.

Nair, R. M. (2005) “Inland water transport-Policy support must go full steam”. The Hindu (Business Line). Monday, Aug $15 . \quad$ Retrieved from: http://www.thehindubusinessline.in/2005/08/15/stories/2005081500110600.htm

National Council of Applied Economic Research (NCAER) (2006) "Economic Yield and Feasibility of the Inland Waterways Mode of Cargo". Quarterly Newsletter. New Delhi, India. Connexions, 2(5): 2-3.

Nishat, A. (2001) "Development and Management of Water Resources in Bangladesh: Post1996 Treaty Opportunities”. In: Biswas, A.K., and Uitto, J.I. (Eds) Sustainable Development of the Ganges-Brahmaputra-Meghna Basin. United Nations University Press, Tokyo, 80-99

Pauli, G (2010) "Sustainable transport: A Case Study of Rhine navigation" Natural Resources Forum., 34: 236-254. 
Planning Commission (2006) "Report of the Working Group on Water Resources for the XI Five year Plan 2007-2012”New Delhi, India.

Pletcher, K. (Ed) (2011) “The Geography of India: Sacred and Historic Places” Britannica Educational Publishing. New York, 374.

Rangaraj, N. and G. Raghuram (2007) "Viability of Inland Water Transport in India”. ADBIndia Resident Mission: INRM Policy Brief No-13: 13.

Rahaman, M. M. (2009) "Principles of Transboundary Water Resources Management and Ganges Treaties: An Analysis”. Water Resources Development, 25(1): 159-173.

Sriraman (2010) "Long term perspectives on Inland Water transport in India" RITES Journal, 12(1).

UNCTAD [United Nations Conference on Trade and Development] (2009) "Review of the Maritime Transport -2009". Chapter 5. United Nations (UN) - New York and Geneva (Retrieved from: http://unctad.org/en/docs/rmt2009ch5_en.pdf).

UNEP (2011) "Low Carbon Transport in India"- Stakeholders' Consultation Workshop: 1820 October 2011, India Habitat Centre, New Delhi, India [http://www.unep.org/transport/lowcarbon/news_events.aspCarbon].

UNEP (2011) "Towards a Green Economy: Pathways to Sustainable Development and Poverty Eradication - A Synthesis for Policy Makers" [Retrieved from www.unep.org/greeneconomy].

Verghese, B. G. (2001) "From Dispute to Dialogue to Doing. In: Biswas, A. K., and Uitto, J. I. (Eds) Sustainable Development of the Ganges-Brahmaputra-Meghna Basin” United Nations University Press, Tokyo, 163-189.

Verghese, B. G. (2006) "Water resources in the northeast: Development options in a Cooperative Framework” Background Paper, Centre for Policy Research, 19-21. 